Historic, Archive Document

Do not assume content reflects current scientific knowledge, policies, or practices. 

62.57

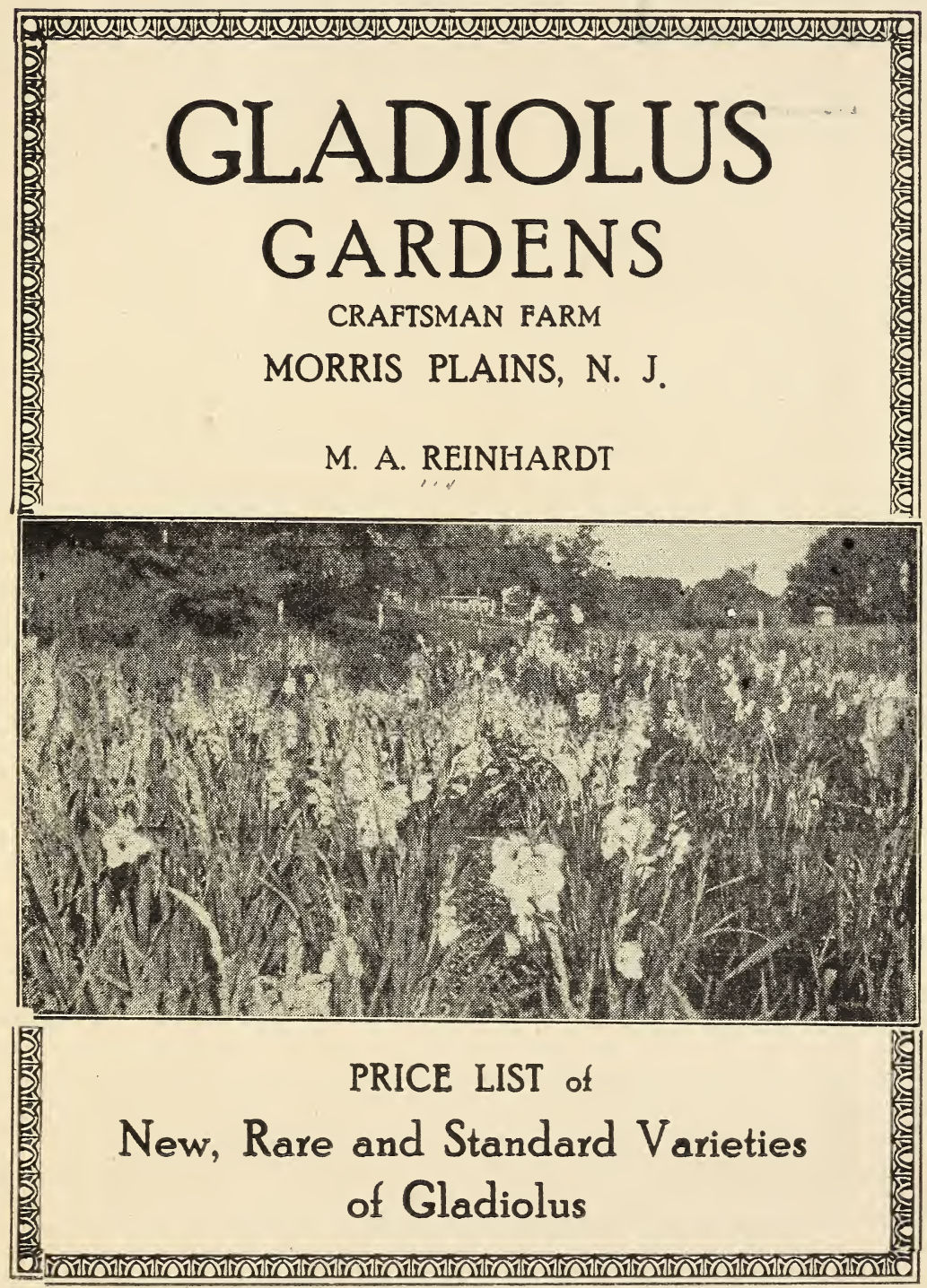




\section{ORDER SHEET}

\section{ISSUED BY \\ M. A. REINHARDT, GLADIOLUS GARDENS Morris Plains, N. J.}

Located on the Craftsman Farm, on the Mount Tabor Road

Date

Amount Inclosed

Your Name

(Please write distinct?y)

P. 0 .

Street

State

County

Orders for less than 50 cents may be sent in stamus

Quantity

NAME

PRICE

Would appreciate

the names and addresses of your friends who grow Gladiolus, and we will remember you with a few extras. 
Glad Greetings to My Customers and Friends:

Thanking you for your patronage, I hope you enjoyed your Glads.

We harvested about a million bulbs of over 1100 varieties. We have some fine ones of our own originations, some of which we hope to offer next year.

There are three varieties that I would especially call to your attention:

Glendale-A new one. This was most admired of many others at the Fair, Morristown, N. J.

Mrs. J. W. Valentine--Originated by the lady of that name. We have sent it to different ones for trial. This is what the H. G. Hastings Seed Co., of Atlanta, Ga., writes: "Ft is an exceptionally good variety and we were well pleased with its growth and its heavy blooming qualities. It is easily remembered even with nearly one thousand varieties in trials this year (1924) and certainly comes in the first dozen."

Los Angeles-Here we have the forerunner of a new race of Gladiolus. This is a "cut and come again" Glad. The one objection to the Glads has been that as a garden flower it is too quickly gone. But this variety sends up a second, third and fourth spike from its first spike thus doubling the length of its blooming season. If I could add but one variety to my collection this year this would be the one.

As our stock is limited, please order early.

About errors. While we try not to make any, but this spring, while we were moving to our new location, some varieties became mixed. So if anything was not just right, please don't scold, but let us know and we will gladly make it right.

M. A. REINHARDT, Morris Plains, N. J. 


\section{DIRECTIONS FOR CARE AND CULTURE OF GLADIOLUS.}

Gladiolus, although one of the prettiest flowers and the best for cutting, will grow most anywhere except in the shade.

They should have plenty of sun. Never plant under a tree or among shrubbery that will shade or crowd them. Yet they may be planted among other flowers and will give a good effect.

They should be planted 4 or 5 inches in light soil, a little less in heavy soil.

Plant them about 4 inches apart in a row or 8 inches where you make a solid bed.

It is best to manure your place in the fall, as no fresh manure should come in touch with your bulbs. After planting you may apply any good fertilizer near the row.

In dry weather water thoroughly but do not allow any crust to form but cultivate after each rain or watering.

Plant as soon as the ground is mellow up to the latter part of June.

Don't remove hulls from bulbs before planting.

Don't plant upside down.

Don't cut spikes too low, leave 4 or 5 leaves on plant.

Cut off your leaves at digging time. Allow to dry a few days in the open, then store away in a dry place with a temperature between 35 and 40 degrees.

You may clean them during the winter, throwing away the old shriveled bulb.

Keep in shallow boxes or paper sacks. 


\section{PRICE LIST}

AMERICA-Light lavender pink

AMERICAN BEAUTY-Brilliant American Beauty color, with creamy yellow throat, many open at a time

AMERICAN INDIAN-Fine velvety red, deeper red throat. Very ruffled

ARIZONA-(K) Tall spike with large rose pink blossoms

5c Each

$50 \mathrm{c}$ “

$20 \mathrm{c} "$

10c Each

AVALON-An extra choice blush white, very beautiful throat

BARON HULOT-Dark violet blue

$15 \mathrm{c}$ "

$15 \mathrm{c}$ “

BEST VIOLET-Rich violet color

$10 \mathrm{c}$ “

BUMBLE BEE-Large flower, salmon rose pink, throat of deeper color

$25 \mathrm{c}$ “

BYRON L. SMITH-One of the very best. Most refined lavender pink on white ground. Exceedingly fine as a cut flower. Color equal to very fine cattleya orchid

50 c “

CAPTAIN BOYNTON-A fine lavender color with

a darker spot on lower petals. A beauty

CINNABAR-A self colored red, many open. A grand and brilliant red. Ruffled

$75 \mathrm{c}$ “

$20 \mathrm{c}$ “

CINNAMON BEAR-Rich deep violet red, deeper throat. Ruffled

$20 \mathrm{c}$ “

CHATEAU THIERRY-Very large brilliant orange scarlet

CONSPICUOUS-Light blue. The pansy Gladiolus

CRACKER JACK-Dark red, spotted maroon _.._-_

CRIMSON GLOW-Deep brilliant crimson, with darker shades

$15 \mathrm{c}$ “

$15 \mathrm{c}$ “

5 c “

$15 \mathrm{c}$ “

CRYSTAL WHITE--Snow white, with purple markings

DAISY RAND-Soft salmon pink

$5 c$ c

$15 \mathrm{c}$ “

DAWN-Salmon pink with darker blotch _ _

E. J. SHAYLOR-Deep rose pink, ruffled. Very fine

EVELYN KIRTLAND-Beautiful rose pink

5c "

$20 \mathrm{c}$ “

$10 \mathrm{c}$ “

ELF-Lemon yellow when in bud, fully open flowers are snow white, lemon yellow lip. One of Diener's new ones 
EMPRESS OF INDIA-Rich, dark velvety red, almost black

FIRE-Large fiery red

$10 \mathrm{c}$ “

FLORA-Large vigorous yellow _..._.___..._.

GLENDALE-Dark American Beauty rose color. Many large open blooms. Exceedingly attractive. New

$10 \mathrm{c}$

$10 \mathrm{c}$ “

GOLDEN KING-Large golden yellow, red blotch

GOLDEN MEASURE-Pure golden yellow, very tall and massive

$15 \mathrm{c}$

$10 \mathrm{c}$

$35 \mathrm{c}$

GOLDEN WEST-(Pacha) Orange scarlet

$10 \mathrm{c}$ “

GRETCHEN ZANG-Soft . pink, blending into scarlet

HALLEY-Salmon pink, early, large

$10 \mathrm{c}$

$5 c$

HELEN FRANKLIN-White, violet stripes on lower petals, ruffled

$10 \mathrm{c}$

HELEN TODD-Light rose pink with deep colored seam around entire edge of flower, deep scarlet center, strong spike

HERADA-A self colored glistening mauve

$5 c$ c

$15 \mathrm{c}$ “

IDA VAN-A most beautiful deep salmon red or flaming pink

IVORY - White, ruffled

JOE COLEMAN-Large vigorous rich red

KUNDERDI GLORY-Beautiful creamy apricot with fine red marking on lower petals. A very famous variety, the first ruffled one.

$10 \mathrm{c}$ “

LE IMMACULEE-Pure white, many open.

$10 \mathrm{c}$ “

LE MARSHAL FOCH-A new Holland variety, very delicate pink with enormous wide open flowers, very early

LENA GRAETZ-Almost pure white (new)

$10 \mathrm{c}$ “

$10 \mathrm{c}$ "

LILY WHITE-A good and early white variety 10c “

LILLIAN WEBB-Strawberry pink with light maroon velvety centers

LITTLE DIAMOND-Rich salmon pink ruffled

5 c “

5 c “

LOS ANGELES-Shrimp pink, tinted orange, with orange tinted carmine throat. The "cut and come" variety.

LOUISE-A magnificent new lavender. Large wide open flowers with dark wine penciling on lower petals. Extra fine

MARY FENNELL-Light lavender, tinged soft pink, yellow throat

\section{$20 c$}

$15 c$ c 
MATTHEW CRAWFORD-Creamy pink. Very massive and showy. Very fine

MR. MARK-Light blue. Beautiful color and fine, sturdy grower

MOTTLED BEAUTY-Extra large, well ruffled. The flower has a most strikingly mottled and flaked ground color with large and beautifully penciled blotches

$10 \mathrm{c}$ “

$50 \mathrm{c}$

MRS. DR. NORTON - Several white blossoms daintily tinted with pink, deepening toward the edges. A creamy blotch of sulphur yellow speckled at base with Tyrian rose

MRS. FRANCES KING-Very tall, flame scarlet. Many large flowers open at once-

MRS. FRANK PENDLETON-Bright rose pink with very large crimson blotch

$10 \mathrm{c}$ “

MRS. H. E. BOTHIN-Light geranium pink, flame scarlet center. Ruffled.

MRS. J. W. VALENTINE-Light salmon-pink. Flaked deeper; lighter towards throat. Many open. Good keeper. Offered first time this season. Early

$25 c$ "

$50 \mathrm{c} "$

MRS. O. W. HALLADAY-A deep golden cream color, petals flushed all around the edges with a deep border of salmon pink. A beauty

MRS. WATT-American Beauty shade

MRS. W. E. FRIJER-A very showy orange scarlet

MRS. WILLIAM KENT-Light fawn to light ashes of roses, old rose throat sometimes striped rose pink. Flowers large and color very delicate

MURIEL-One of the loveliest of the light blues, dark spot in throat.

$15 \mathrm{c}$

$10 \mathrm{c}$

$15 \mathrm{c}$

$25 \mathrm{c}$ “

$20 c$ c

MYRTLE-Clear dainty rose pink, melting into a throat of creamy white

NIAGARA-Nanking yellow, nice shaped flower on strong spike

NORA-Light lavender, darker blotch

ORANGE GLORY-Orange colored with beautiful lighter throat, ruffled

PEACE-Very large white with light lilac featherings in throat.

$25 \mathrm{c}$ “

PINK BEAUTY-Rose pink with lovely dark red blotches on lower petals. Very early

PINK BEAUTY BLOTCH-Large-flowered strong plant, fine pink with beautiful blotches on lower petals 
PINK PERFECTION-A most lovely flower of a LaFrance pink

PRESIDENT MENOCAL-Yellow, pink border, tall spike, ruffled

$15 c$ c

PRIDE OF GOSHEN-Flesh pink with ruffled petals, a robust grower

$10 \mathrm{c}$ “

PRINCE OF INDIA-A most unique blending of dull smoky blue tones, shading from light to dark, a very handsome novelty.

$25 c$

PRINCE OF WALES-Clear salmon, yellow throat $10 \mathrm{c}$ “

PRINCIPINE-Large open flowers, orange red, with white blotch

$10 \mathrm{c} “$

PROPHETESSE-Flesh white with large dark maroon velvety blotches on lower petals

$10 \mathrm{c}$ “

PURPLE GLORY-Deepest velvety maroon red, with almost black blotches, ruffled. A giant_____-_-

$50 \mathrm{c}$ “

QUEEN OF THE NIGHT-Deep maroon almost black velvety, very large

RED, WHITE AND GOLD-Upper portion of bloom pure white, lower petals entirely of a rich yellow with a beautiful red blotch

$15 c “$

ROEM VAN KENNEMERLAND-New beautiful deep rose with yellow blotch. Flowers very large and very attractive.

ROSE ASH-Old rose blended ashes of roses, odd and beautiful.

SCARSDALE_Large lavender pink_-___-__-_._-_-

SHEILA-Salmon pink

SILVER MOON-White tinted blush over entire flower. Beautiful throat. Ruffled._._...--

SIR ROGER CASEMENT-Very dark red, very ruffled, giving the flower an appearance of double

SCHWABEN-Sulphur yellow, small red markings on lower petals

SPLENDORA-Splendid, very dark wineblack. A fine rich, distinct sort

SENTINEL-Tall, large, pure rose pink, with elegantly white penciled iris-like throat

$10 c$ “

$35 c$ “

$10 \mathrm{c}$ “

$25 c$ “

$15 c$ c

$15 c$ c

$5 c$ c

$15 c$ “

$10 \mathrm{c}$ “

SWEET LAVENDER-Lavender with maroon blotch

VIOLET BEAUTY-Tall, large, cerise-violet. Grand red throat blotches. Ruffled, beautiful

$20 \mathrm{c}$ “

$20 \mathrm{c}$ “

WHITE BELLE-Tall, strong. Delicate blush white, deeper at edges. Beautiful throat. Ruffled-- 25c “ 
WHITE GIANT-Immense. Easter lily-like white flowers

WHITE GLORY-A good, ruffled white, with iris blue throat

$25 c$ c

WHITE IVORY-Like "Ivory" but taller and still more intensely ruffled. Snow-white ground, with beautiful red blotches on lower petals.... 30c "

WILBRINK-A delicate creamy pink with throat markings of Halley of which it is a sport. Very early and beautiful

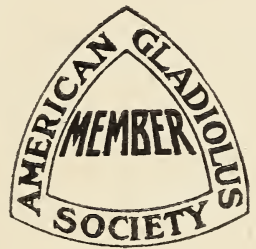

For price of dozen multiply price of each by ten. For larger lots write us.

ORDER EARLY - Bulbs will be mailed in March or April.

We send Cut Flowers, a dozen in a box prepaid, for \$1.00. Have a box sent to one of your friends or yourself. 


\section{PRIMULINUS HYBRIDS \\ The New Race of Gladioli}

A new and beautiful race of Gladioli has been produced by using the fine yellow species Primulinus or Maid of the Mist, in crossing with the older existing strains. The varieties resulting are disting'uished mainly for their varying shades of yellow, graceful slender stems, and airily poised and hooded flowers.

ALICE TIPLADY-A grand large Primulinus of most beautiful orange saffron color. Very choice

15c Each

ALTAIR-Extra tall, of finest salmon saffron. A grand color ---

ARGO-Grand, tall, large. The Primulinus Myrtle 15c “

GOLD DROP-An extra large pure deep yellow, with beautiful red line on petals. Ruffled _... 10c

MAIDEN BLUSH-One of the most attractive Primulinus. Cream pink $15 \mathrm{c}$ “

MIDSUMMER DREAM-A large beautiful geranium red. Showy, fine

PRIMUNELLA-A grand ruffled butterfly, orchidlike flower. Beautiful

ROANOKE-A vigorous and large, rich yellow. Very fine

TOPAZ-Salmon pink

\section{GLADIOLUS IN MIXTURE}

A good mixture is perhaps the most economical

way to buy, especially when you do not care for their names or care to keep them separate.

They are cheaper because we save time and expense of labeling them.

They are grown separately, and mixed when we put up the order. The mixture contains about 30 or more varieties to the 100 .

IDEAL MIXTURE-This was well spoken of by

all who purchased them last year. 100 
GRANT MIXTURE-This contains ruffled as well as plain petaled varieties. This was highly praised by every one. 100

ORCHID MIXTURE-This is a superior mixture and contains some of our best varieties. This would cost several times the price asked for if bought separately, and this would hardly be equalled anywhere at the price. 100

\section{COLLECTIONS}

(COLLECTION A) - Twelve bulbs, all different, all labeled, which would cost separately $\$ 1.50$, for only

The above was so much admired last year that we have been led to put up another one with all different varieties from the above under the name (COLLECTION B-This if you already have the former, by adding this you would have no duplicates.

(COLLECTION B)-Twelve bulbs, all different all labeled; which would cost separately $\$ 1.50$, for only

(COLLECTION C) - Twenty-five bulbs, all differs ent, all labeled. Contains some choice ones, worth $\$ 5.00$, for only

\section{DAHLIAS}

Our dahlias were not planted till after the 20th of July and many had become mixed. They did not all bloom so we could not identify them and thus we do not offer any of these - this year.

We have, however, two new ones.

ROBERT TREAT - Decorative. A real cerese Almost American Beauty color, good bloomer, size of flower 6-9 in.

$\$ 5.00$

SUNRISE-A new single, was awarded the first prize as the best new single at the Dahlia show in New York. Apricot with orange, very free bloomer 




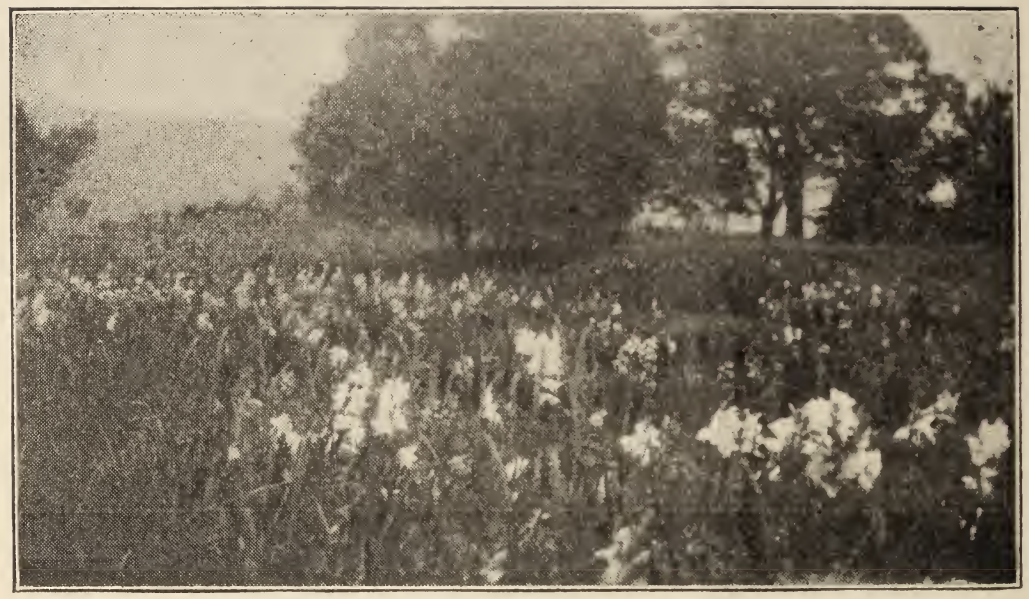

